\title{
Chondrocutaneous Branchial Remnants or Cartilaginous Choristoma: Terminology, Biological Behavior and Salience of Bilateral Cervical Lesions
}

\author{
Kondrokutanöz Brankial Artıklar veya Kartilajinöz Koristomlar: Terminoloji, \\ Biyolojik Davranış ve Dikkat Çeken Bilateral Servikal Lezyonlar
}

\author{
Bal CHANDER ${ }^{1}$, Sunder Singh DOGRA ${ }^{2}$, Rashmi RAINA ${ }^{1}$, Chanderdeep SHARMA ${ }^{3}$, Renu SHARMA ${ }^{1}$
}

Department of ${ }^{1}$ Pathology, ${ }^{2}$ ENT, and ${ }^{3}$ OBG, Dr. R.P.G. Medical College, HIMACHAL PRADESH, INDIA

\section{ABSTRACT}

Objective: To present and critically examine the spectrum of chondrocutaneous branchial remnants or accessory pinna, including rare case of bilateral cervical lesions, and to explain the basis of the biological behavior.

Material and Method: Five cases of pediatric chondrocutaneous branchial remnants or accessory pinna were included. The ratios of the longest dimensions of the external ear to that of the accessory tragus/chondrocutaneous branchial remnants were calculated.

Results: The size and rate of growth of chondrocutaneous branchial remnants or accessory pinna were found to be inversely proportional to the distance between the lesions and the normal pinna.

Conclusion: The current literature and norms of terminology dictate that two different terminologies for lesions that are essentially histologically identical should be avoided. Chondrocutaneous branchial remnants, accessory pinna/tragus and chondroid/ cartilaginous choristomas are identical lesions with similar pathogeneses and should be referred to as choristomas.

Key Words: Cartilage, Choristoma, Head and neck neoplasms

\section{INTRODUCTION}

The presence of heterotopic cartilage under the skin in the head and neck region constitutes a cartilaginous choristoma. Theoretically the choristomas can be of different types such as heterotopic presence of thyroid gland, bone, glial tissue and salivary gland, etc. The common theme shared by different choristomas is that these are very slow growing and benign. The excision is generally done either for cosmetic purposes or to rule out any possibility of malignancy (1). External cartilaginous choristomas in the head and neck region are now named chondrocutaneous

(Turk Patoloji Derg 2014, 30:195-200)

Received : 16.05.2013 Accepted : 19.07.2013

\section{ÖZ}

Amaç: Bilateral servikal lezyon olarak ender sunulan kondrokutanöz brankial artıklar ya da aksesuar pinna spektrumunu irdelemek ve biyolojik davranışını tartışmak.

Gereç ve Yöntem: Beş çocukluk çağı kondrokutanöz brankial artık ya da aksesuar pinna olgusu sunulmaktadır. Dış kulak ile aksesuar tragus/kondromatöz brankial artıkların en uzun boyutlarının oranları hesaplandı.

Bulgular: Kondrokutanöz brankial artık ya da aksesuar pinnanın boyutu ve büyüme hızı, lezyonlar ile normal pinna arasındaki mesafe ile ters orantilıydı.

Sonuç: Geniş literatür taraması ve terminolojik açıdan bakıldığında, temelde histolojik olarak aynı olan lezyonların farklı terminoloji ile anılmasından kaçınılmalıdır. Kondrokutanöz brankial artıklar, aksesuar pinna/tragus ve kondroid/kartilajinöz koristomlar patogenez açısından benzer lezyonlar olduklarından koristomlar olarak isimlendirilmelidir.

Anahtar Sözcükler: Kıkırdak, Koristoma, Baş boyun neoplazmları

branchial remnants or accessory pinna with the implication that all these lesions are remnants of one of the branchial arches. However, the similar heterotopic cartilage in the mouth, tonsillar region or pharynx is named cartilaginous choristoma even though the biological behavior and histopathological features of all these lesions regardless of the site are identical to the heterotopic presence of mature cartilage covered by overlying skin or mucosa (2). We present 5 cases of chondrocutaneous branchial remnants/ accessory pinna/ tragus or cartilaginous choristoma located in the neck and cheek.

Correspondence: Bal CHANDER

Dr. R.P.G. Medical College, Department of Pathology,

HIMACHAL PRADESH, INDIA

E-mail: ssst419@hotmail.com Phone: +91898 8159250 


\section{MATERIAL and METHODS}

Five cases of chondrocutaneous branchial remnants or accessory tragi were seen in our hospital in the last two years. All the cases, except for the fetus referred for autopsy, were operated and the lesions removed. The ratios between longest dimensions of external ear to that of accessory tragus/chondrocutaneous branchial remnants were calculated since the lesions located at different anatomical locations were of different sizes, and also based on the hypothesis discussed below.

\section{RESULTS}

There were 3 males and one female with a mean age of 4 years and in addition there was a 30-week-old male fetus that had suffered intrauterine death.

The ratio of the longest dimension of the pinna to longest dimension of the accessory pinna/ chondrocutaneous branchial remnants was calculated.

1. A 3.5-year-old male presented with an asymptomatic cutaneous mass since birth measuring $2 \times 2 \times 1 \mathrm{~cm}$ on the right cheek (Figure 1). Ratio: 5.

2. A 6-year-old male presented with asymptomatic bilateral cervical region masses since birth measuring $0.6 \times 0.5 \times 0.3$ and $0.5 \times 0.4 \times 0.4 \mathrm{~cm}$. The left lesion was lower than the right (Figure 1). Ratio: 11.

3. A 5-year-old male presented with an asymptomatic unilateral cervical region mass since birth measuring 1x1x1 cm. Ratio: 10.

4. A 30-week-old male fetus with intrauterine death. The autopsy revealed hydrocephalus, left microtia, midline clefting of the lips and both hard and soft palate, bilateral nasal ala agenesis, thymic hypoplasia and dextrocardia. Bilateral preauricular accessory tragi measuring 1x0.5x0.4 cm each were present (Figure 2). Ratio: 2 .

5. A 1.5-year-old female with asymptomatic bilateral appendages anterior to the tragus. The growth rate of the accessory structures were similar to the normal pinna. The left and right lesions measured $1.3 \times 1 \times 0.4$ and $1.4 \times 1 \times 0.5 \mathrm{~cm}$ respectively. In addition, nodules measuring $0.4 \mathrm{~cm}$ in longest dimension and located at the entrance of the external auditory meatus on both sides were also seen (Figure 2). Ratio: 3.3.

The masses were extremely slow growing in all cases and the patients were brought to the hospital because the masses were becoming too noticeable. Cartilage could be discerned on palpation and seen on gross examination in all the lesions. There were no associated malformations except for the fetus. No family history was present in any of the cases.

All the masses were excised and sent for histopathological examination, which revealed similar features in the form of mature cartilage in the subcutis. The overlying skin was within normal histological limits (Figure 3).

The relevant ratios were 11 and 10 for the cervical masses and 5, 2 and 3.3 in cases of accessory tragus located in the preauricular region and cheek. The lesions in the neck were decidedly smaller compared to the preauricular region and cheek.

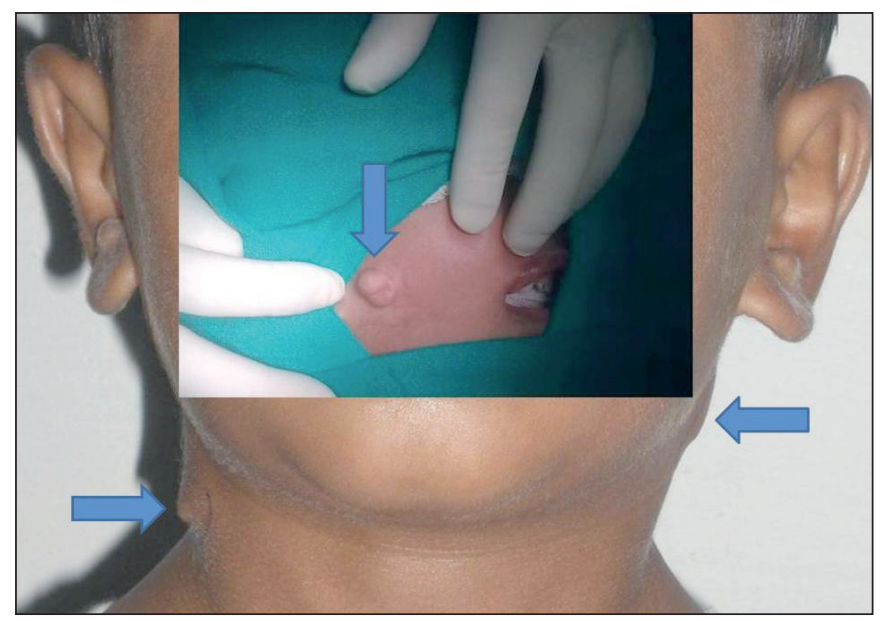

Figure 1: Bilateral chondrocutaneous branchial remnants (right and left block arrows). Inset: Accessory pinna, preauricular region.

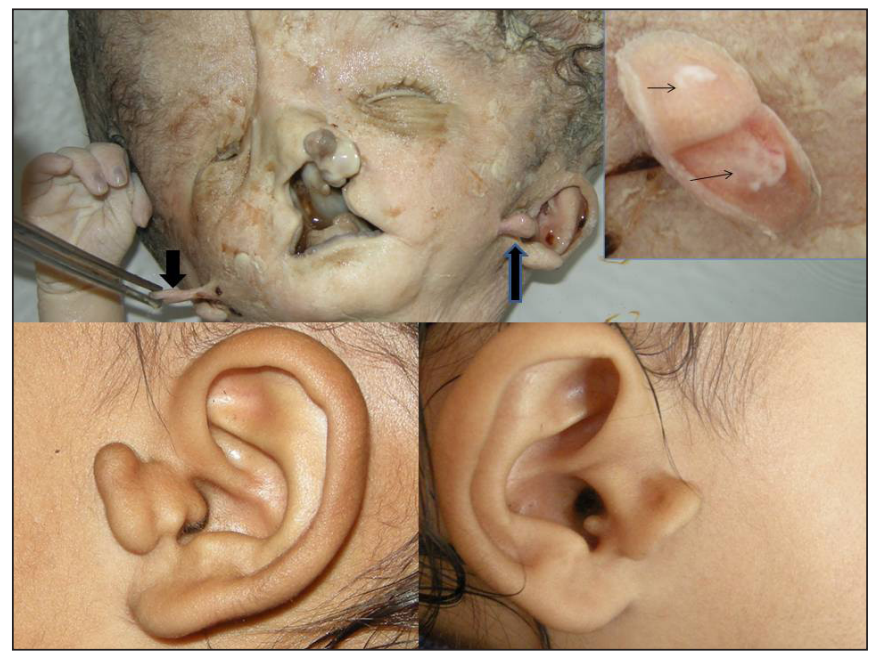

Figure 2: Fetus: Bilateral preauricular accessory pinnas (up and down block arrows). Inset: Cut section of accessory pinna showing whitish cartilaginous body (right line arrows). Lower right and left accessory pinna of case 5 . 


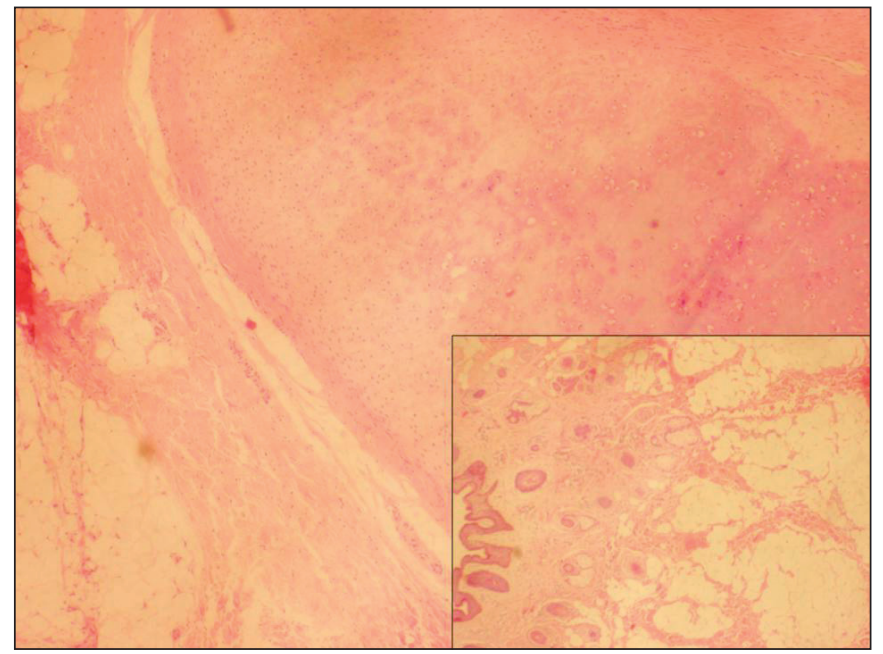

Figure 3: Section from accessory pinna showing mature cartilage and surrounding adipose tissue (H\&E; $\mathrm{x} 4)$. Inset: Overlying adipose tissue and skin.

\section{DISCUSSION}

At the outset it would be prudent to state that the histomorphological features of chondrocutaneous branchial remnant, accessory pinna or tragus and cartilaginous or chondroid choristoma are identical. On microscopic examination, all the lesions show cartilage, surrounding connective tissue and stratified squamous epithelium at the surface. The different names are used for identical lesions based solely on their anatomic locations. The approach is unwarranted and in fact goes against the norms of nomenclature. It is difficult to imagine different names based on location for teratoma or squamous cell carcinoma, for example.

In the following discussion, chondrocutaneous branchial remnant, accessory pinna or tragus shall refer to the lesions found externally in the head and neck region whereas internal lesions are referred to as cartilaginous or chondroid choristoma except when stated otherwise and then onwards.

Chondrocutaneous branchial remnant is the universally accepted term for the presence of heterotopic cartilage subcutaneously in the cervical region. The nomenclature was accepted in 1997 prior to which these lesions were referred to by different names including accessory pinna or tragus owing to lack of consensus. The essential histopathological feature is the presence of cartilage in the subcutis or lower dermis, with overlying dermis and skin (1).

Accessory pinna or tragus is still a preferred term for lesions located in the preauricular region.
It should be appreciated that while the presence of cartilage is heterotopic, the surrounding connective tissue and overlying skin are obviously not. The latter are similar to the surrounding skin with subcutis. The 'chondrocutaneous' term implies both cartilage and skin as one unit with a common origin, which is not true. The epidermis is derived from ectoderm whereas neural crest cells supply the dermis for face and neck, the craniofacial cartilage, and bone among others.

There are various theories addressing the pathogenesis of cartilaginous choristomas. One of them, proposed by Atlan et al. and widely quoted, is the 'left behind theory' apropos chondrocutaneous branchial remnants in the cervical region, which proposes that a few cells of the first and second pharyngeal arches, the contributors of auricular hillocks 1 through 6, are left behind in the neck during embryonic migration and the heterotopic cervical region cartilage is the consequence of cartilaginous differentiation of the purported cells (3).

It must be noted that the first and second pharyngeal arches in addition to ear also participate in formation of tongue, maxilla, mandible, palatine tonsils and pharynx (4).

Any hypothesis should be anatomically and embryologicaly sound and should be able to explain the location, incidence and natural history of the lesion and also similar closelyrelated lesions. The hypothesis of Atlan et al. appears to be incomplete since it treats cervical lesions as separate from identical lesions elsewhere from a histopathological perspective. In addition, 'behind' is quite vague and relative in the context of the dorso-ventral, antero-posterior and left-right axis of the body along with the direction of embryonic cellular migration. Though plausible to an extent for lesions confined to the cervical region, it may be a tad difficult to reconcile the theory with similar lesions in locations such as the tongue, eyes, external ear canal, tonsil and pharynx along with the preauricular region. If one were to modify this hypothesis, 'behind' will have to be replaced by 'overshot' or' displaced laterally/medially' in some locations if all the cartilaginous choristomas have to brought together under one term. Even in this scenario, one would end up calling external lesions 'chondrocutaneous branchial remnant' whereas internal lesions would have to contend with the term 'cartilaginous/chondroid choristoma' because the terms chondrocutaneous branchial remnant or accessory pinna/ tragus for a lesion located for instance in tongue will make no sense, especially when the nose nearer by also has cartilage. Therefore it appears that different names for essentially the same lesions from a histopathological perspective are unavoidable. 
One way to circumvent this unfortunate predicament may be to change the perspective. The term choristoma refers to the presence of heterotopic tissue anywhere in the body (2). It may be considered that it is the heterotopic cartilaginous body that is the active entity while the surrounding connective tissue along with overlying stratified squamous epithelium are passively stretching over it. The changed perspective can reconcile cartilaginous/ chondroid choristomas elsewhere in the head and neck region with similar histopathological features as that of chondrocutaneous branchial remnant or accessory pinna/ tragus, except for the oro-pharyngeal mucosa substituting the skin in the former $(2,5)$.

In other words, only heterotopic cartilage needs to be considered and hence the term 'cartilaginous choristoma', similar to universally accepted 'osseous choristoma', accompanied by the location should be a more appropriate name for such lesions in lieu of different terms for essentially the same lesion.

In the following part of discussion, all these lesions shall be referred to as cartilaginous choristoma. Cartilaginous choristomas, in addition to a subcutaneous location in the head and neck, have also been reported from as diverse locations as the eye, nasopharynx, tongue, ear and middle ear $(2,5)$. Confinement of most of these lesions in the head and neck region is striking.

One can hypothesize that it is the proliferation of immature cell rests in the head and neck region which, in a few cases, result in cartilaginous choristoma and that pluripotent cell rests need not be necessarily 'left behind'. It would be similar to the presence of supernumerary nipples in areas such as sole of the foot, thigh and over the scapular region, etc. for which 'left behind' would make no or little sense from an embryological perspective (6).

Perhaps 'anomalous differentiation' in lieu of 'left behind' would be a better phrase. The former can explain cartilaginous choristoma in locations other than the neck, not unlike supernumerary nipple in regions other than milk line. The anomalous differentiation and consequent heterotopic tissue by inference should originate from immature pluripotent cells. The stimuli for the process remains unknown but it should be mostly a stochastic event given the lack of family history in most of these cases and also the fact that most of them are unilateral $(7,8,9)$.

If we accept that most of these lesions are non familial or random then we can also explain the existence of osseous choristomas in the same region since bone replaces cartilage in the embryo and both are of mesodermal origin. Indeed, there are case reports and series of osseous choristomas in the head and neck region and by extension one would expect the rare combination of 'chondrolipoma' $(10,11)$.

One striking difference between the internal cartilaginous choristoma and external ones in the head and neck is that the former are diagnosed in the older age group and the latter are congenital. One way to explain this discrepancy would be by considering the location and rate of growth.

Cartilaginous choristoma on the skin are external and superficial and hence they come to clinical attention much sooner. On the other hand, the rest of the cartilaginous choristomas are asymptomatic internal lesions and hence escape attention till the increased size makes them noticeable.

There is not even a single case report detailing fast growth in cartilaginous choristomas regardless of the site. According to the published literature, they appear to be either extremely slow growing or not growing at all $(1,2,5,10,11)$. The three cases that we are reporting did not have history of appreciable growth over time whereas case number five did show appreciable growth.

Since these lesions are non neoplastic, the heterotopic cartilage has to be dependent on necessary growth factors which must be quite scarce indeed as this is not the normal site for cartilage, and this inevitably results in extremely slow growth rate. However, the case number five showed a growth rate almost parallel to the growth rate of the pinna, which is to be expected because the location of the anomalous structures was very close and in fact almost contiguous to the normal structure. The lesions at close proximity with comparative higher growth rates are likely to result from a microenvironment conducive to the growth of cartilage. The conclusion is supported by the ratios mentioned above where these are 2 and 3.3 for the lesions placed close to the pinna and 11 and 10 when the lesions are located in the cervical region. The choristoma on the cheek gives a ratio of 5 . Hence it appears that the size of lesion is inversely proportional to the distance between the lesion and the pinna. The probability of neoplasm in these lesions has to be extremely low given the very low rate of cell division. There is no reported case resulting in malignant degeneration.

In order to explain the bias in favor of a head and neck location of these lesions we may have to assume that there might be a higher probability of anomalous differentiation in a region where all three germ layers and the derivatives are in close proximity to each other. It would be similar to higher probability of random mutations in rapidly dividing cell populations. 
There is reported association of the rare Goldenhar complex (facioauriculovertebral syndrome, hemifacial microstomia) with unilateral external lesions in a proportion of cases but none with bilateral lesions (12). The association can perhaps be explained by taking into consideration the fact that every syndrome or disease has a spectrum of severity that determines the survival of the individual. The association is seen because some of the fetuses are viable enough to reach maturity with unilateral facial and vertebral malformations along with cartilaginous choristomas.

On the other, hand bilateral lesions with other malformations are probably not seen because such severe bilateral malformations are incompatible with survival and the fetus is aborted. This theory is plausible because the fate of anomalous cells must be decided early on during embryogenesis to maintain the symmetry of such lesions and the chances of associated malformations should be theoretically higher together with the chances of abortion. Hence the surviving individuals with bilateral lesions have only the mildest anomalies.

The fetus that had suffered intrauterine death detailed above is a case in point. There was not only symmetry of the preauricular lesions but also of the malformations of the lips, palate and nose, along with hydrocephalus. The case fits in with the abovementioned logical framework.

A literature review reveals a surfeit of cases without associated Goldenhar syndrome. It may hence be concluded that whereas external lesions are a consistent feature of the Goldenhar syndrome, the opposite is not true (1,3,7-9). The cases we are reporting did not have any indication of Goldenhar syndrome.

There are two other conditions in which cartilage can be seen in a subcutaneous location. The first one is hamartoma and second is cartilaginous metaplasia. Asahina et al. reported a case with multiple lesions clinically diagnosed as accessory tragi but histopathological examination revealed only hair follicles and no cartilage. The authors proposed that these lesions reported as hair follicle nevi should be considered as incomplete accessory tragi and further recommended that chondrocutaneous branchial remnants and hair follicle nevi / incomplete accessory tragi should be considered as part of same spectrum that is hamartomatous in nature (13). The logic is specious since hamartoma by definition is a benign mass composed of architecturally disorganized native tissue and therefore is not a correct term for these cases since the cartilage is not native. Cartilaginous metaplasia can also be seen, in general secondary to trauma or as a part of neoplasia. However, both are excluded in cases of congenital lesions and because of their biological behavior and history.

All the cases we are reporting except one were male patients and it appears that there may be a predilection for the male sex.

In conclusion; we propose that chondrocutaneous branchial remnants or accessory pinna/tragus should be considered as cartilaginous choristomas and referred to as such, and that all choristomas have a similar pathogenesis and the differentiation of pluripotent cells can take disparate directions depending on the availability of different growth factors. The growth rate of these lesions may be significant and dictated by the location, contrary to popular notion. Preauricular lesions are likely to be bigger than cervical lesions. Based on the hypothesis presented, we also predict that bilateral symmetrical external lesions are most likely to be either innocuous as sole lesions or fatal when associated with other malformations.

\section{REFERENCES}

1. Oztürk H, Ozdemir T, Demirbağ S, Atabek C, Sürer I, Safali M, Cetinkurşun S. Bilateral cervical chondrocutaneous remnants: A case report and review of the literature. Turk J Pediatr. 2006;48:175-7.

2. Trowbridge M, McCabe B, Reznicek M. Cartilaginous choristoma of the tongue. A case report and literature review. Arch Otolaryngol Head Neck Surg. 1989;115:627-9.

3. Atlan G, Egerszegi EP, Brochu P, Caouette-Laberge L, Bortoluzzi P. Cervical chondrocutaneous branchial remnants. Plast Reconstr Surg. 1997;100:32-9.

4. TW Sadler. Langman's medical embryology. Philadelphia: Lippincott Williams \& Wilkins, Wolters Kluwer; 2012:260-1.

5. Lee FP. Cartilaginous choristoma of the bony external auditory canal: A study of 36 cases. Otolaryngol Head Neck Surg. 2005;133:786-90.

6. Conde DM, Kashimoto E, Torresan RZ, Alvarenga M. Pseudomamma on the foot: An unusual presentation of supernumerary breast tissue. Dermatol Online J. 2006;12:7.

7. Karaman A, Ceran C, Uğuralp S, Gürses İ, Demircan M. Cervical subcutaneous cartilaginous choristoma in an infant. Inönü Üniversitesi Tip Fakültesi Dergisi. 2007;14:33-5.

8. Jansen T, Romiti R, Altmeyer P. Accessory tragus: Report of two cases and review of the literature. Pediatr Dermatol. 2000;17: 914.

9. Nasser HA, Iskandarani F, Berjaoui T, Fleifel S. A case report of bilateral cervical chondrocutaneous remnants with review of the literature. J Pediatr Surg. 2011;46:998-1000.

10. Kamburoglu K, Ozen T, Sencimen M, Ortakoglu K, Gunhan O. Osseous choristoma of the submandibular region: Case report. Dentomaxillofacial Radiol. 2009;38: 489-92. 
11. Nonaka CF, Miguel MC, de Souza LB, Pinto LP. Chondrolipoma of the tongue: A case report. J Oral Sci. 2009;51:313-6.

12. Rankin JS, Schwartz RA. Accessory tragus: A possible sign of Goldenhar syndrome. Cutis. 2011;88:62-4.

13. Asahina A, Mitomi H, Sakurai N, Fujita H. Multiple Accessory tragi without cartilage: Relationship with hair follicle naevi? Acta Derm Venereol. 2009;89:316-7. 